\title{
Factors Influencing the Red Meat Production in Damietta Governorate of Egypt: Factor Analysis Approach
}

\author{
Bader E. A., S. D. Z. Dawoud, A. F. Helal \\ Department of Agricultural Economics, Faculty of Agriculture, Damietta University, Damietta, Egypt \\ Email address: \\ esbadr@yahoo.com (E. A. Bader), sdawoud@du.edu.eg (S. D. Z. Dawoud), afekrey@yahoo.com (A. F. Helal)
}

\section{To cite this article:}

Bader E. A., S. D. Z. Dawoud, A. F. Helal. Factors Influencing the Red Meat Production in Damietta Governorate of Egypt: Factor Analysis Approach. International Journal of Agricultural Economics. Vol. 2, No. 1, 2017, pp. 15-26. doi: 10.11648/j.ijae.20170201.13

Received: January 22, 2017; Accepted: February 3, 2017; Published: February 25, 2017

\begin{abstract}
In Egypt, the increasing demand for red meat caused by the increasing population, feeding limitations, and increasing cost of production, has become an impetus for meat producers to change the system of production. This study is to find out the main factors that influence the red meat production sector in Egypt. A factor analysis method was mainly used to determine factors which are important in red meat production. The analysis was based on data obtained by means of a questionnaire applied to a random sample of 48 red meat producers in Damietta Governorate in late 2016. The final results showed that five key factors were successfully constructed using factor analysis which are a production factor, a financial factor, an administrative factor, a biological factor, and a technological factor. The production and financial factors are important in producing red meat. The most important variables influencing red meat production are the number of animal units, and the volume of concentrated feed. The success of livestock enterprise depends on a prior experience in the field of meat production. High feed prices and fear of diseases were key challenges for determining red meat production. The availability of livestock feed is the major challenge for the red meat sector. Policy implication focuses on the necessity to increase the domestic production of red meat through facilitating the procedures of animal loans and encouraging the producers to increase the number of meat animals. Also, it becomes a necessity to increase the production of fodder crops and the appropriate vaccines.
\end{abstract}

Keywords: Factor Analysis, Principal Components, Red Meat Production, Egypt

\section{Introduction}

Development of livestock production is considered one of the essential issues. Currently, the livestock production is one of the agricultural subsector in Egypt. Its share of agricultural GDP is about $35.30 \%$. This is represented in red meat, poultry meat, fish, dairy, eggs, and others. The red meat subsector has a relatively direct minor role in the livestock production sector of Egypt, but nevertheless, domestic red meat production makes a valuable contribution to the national food supply, whereas the cash value for it is accounted for about $38.81 \%$ of the total value of livestock production on average during the period (2001-2014) (MALR).

In Egypt, the food problem is regarded as a major strategic issue that attracts intensive attention on all levels. The major sources of calories are plant-based products, representing over $92 \%$ of the total calories consumed per capita per day.
Animal and fish products make up only $6.67 \%$ and $8.06 \%$ of the total calorie availability, respectively, indicating that animal and fish products are relatively expensive sources of calories (Dawoud, 2005). The domestic production of red meat is too insufficient to meet the growing domestic needs of red meat. Therefore, Egypt endeavors to follow a policy that will increase food level of animal protein. Due to the increasing demand for food and especially high value animal proteins caused by rapidly growing population and economic development. Greater emphasis is now being placed on the need to develop the red meat sector, which is considered as one of the essential animal protein resources. There are many factors to be considered in the animal production to develop the red meat sector.

This study is conducted to identify the actual situation of red meat production, to investigate the key factors that 
influence the red meat sector, and to identify the related production and marketing problems. This would be a valuable information providing policy, which may assist policy makers to develop the livestock production sector in Egypt.

\section{Methodology and Data}

The study employed descriptive statistics and factor analysis technique. Descriptive statistics used to summarize the information about the general trend in livestock sector and red meat production in Egypt. The study applied factor analysis model to determine the key factors that influence the red meat production in Damietta Governorate of Egypt.

\subsection{Concepts of Factor Analysis}

Basically, there are two factor analysis techniques: exploratory and confirmatory factor analysis. Both techniques of factor analysis are based on common factor model (Brynaf, J. M., 1994). The main objective of the exploratory factor analysis (EFA) is to determine the number of a common factors influencing a set of variables and to determine the strength of relationship between each factor and each observed variable. The Confirmatory Factor Analysis (CFA) is a tool that is used to test or confirm specific hypotheses about the factor structure for a set of variables. Exploratory factor analysis is simpler to be performed than confirmatory factor analysis, a larger sample size is required for the CFA than for the EFA; for these reasons, the exploratory factor analysis is one of the most commonly used technique for data analysis (Anderson, T.W. 2003).

Principal components analysis (PCA) and exploratory factor analysis (EFA) are most commonly used reduction techniques. These two techniques can be applied to a single set of variables to discover which sets of variables in the set form coherent subsets that are relatively independent of one other. Variables that are correlated with one another which are also largely independent of other subset of variables are combined into factors, factors which are generated are thought to be representatives of the underlying process that have created the correlations among variables (Tabachnick. B. Fidell. L. 1989). Factor loadings is the means of interpreting the role of each variable it plays in defining each factor. The loadings indicate the degree of correspondence between the variable and factor (Hair et al.,1998). Factor loadings are used to group variables with different factors.

In factor analysis, the VARIMAX procedure is the most common used method for factor rotation (Hair et al.,1998; Stewart,1981). This an orthogonal rotation to maximize the variance of the squared loadings of a factor (column) on all the variables (rows) in factor matrix which has the effect of differentiating the original variables by the extracted factor (Garson, G. D., 2008) VARIMAX procedure is to rotate the factor matrix to simplify the interpretation of the columns. Factors are rotated so that the loading are a very high or very low on a particular factor.

\subsection{Model Specification}

The model for factor analysis is represented as follows:

$$
\begin{aligned}
& Y_{1}=a_{11} X_{1}+a_{12} X_{2}+\ldots \ldots \ldots+a_{1 j} X_{j} \\
& Y_{2}=a_{21} X_{1}+a_{22} X_{2}+\ldots \ldots . .+a_{2 j} X_{j} \\
& \begin{array}{lll}
. & . & \cdots
\end{array} \\
& Y_{i}=a_{i 1} X_{1}+a_{i 2} X_{2}+\ldots \ldots \ldots+a_{i j} X_{j}
\end{aligned}
$$

Where Yi represents the $i$ the principal component, $a_{i j}$ the loading coefficients and $\mathrm{x}_{\mathrm{j}}$ the original variables (Anim and Lyne, 1994).

Since the study related the impact of various variables to the production of red meat in Egypt, variables identified to be included as variables in the analysis are expected to be correlated among themselves. This has further been indicated by the correlation matrix presented in the table 2 . in the appendix. Factor analysis approach of data reduction has been applied by using software SPSS.

Factor analysis conducted on 21 variables that are supposed to have an impact on meat production. These variables included the basic variables that are directly related to the production of red meat and other variables related to basic variables.

Variable are as follows: Number of animals each season $\left(\mathrm{x}_{1}\right)$, Amount of production (in tons) $\left(\mathrm{x}_{2}\right)$, Feed cost $\left(\mathrm{x}_{3}\right)$, Cost of veterinary care $\left(\mathrm{x}_{4}\right)$, Value of the herd $\left(\mathrm{x}_{5}\right)$, Potential capacity $\left(\mathrm{x}_{6}\right)$, Current capacity $\left(\mathrm{x}_{7}\right)$, Labor cost $\left(\mathrm{x}_{8}\right)$, Other costs $\left(\mathrm{x}_{9}\right)$, Fixed costs $\left(\mathrm{x}_{10}\right)$, Farm size $\left(\mathrm{x}_{11}\right)$, Profitability $\left(\mathrm{x}_{12}\right)$, Net return per ton of meat $\left(\mathrm{x}_{13}\right)$, Cost per ton $\left(\mathrm{x}_{14}\right)$, Source of animal $\left(\mathrm{x}_{15}\right)$, Number of years of the farm operation $\left(\mathrm{x}_{16}\right)$, Livestock rearing experience (years) $\left(\mathrm{x}_{17}\right)$, Weight at the beginning of fattening $\left(\mathrm{x}_{18}\right)$, Number of sessions $\left(\mathrm{x}_{19}\right)$, Animal breed $\left(\mathrm{x}_{20}\right)$, Animal species $\left(\mathrm{x}_{21}\right)$.

\subsection{Data Sources}

The study was mainly based on the questionnaire survey applied to the livestock owners. The data was collected using a survey from which was distributed randomly to 48 livestock owners in the districts of Damietta Governorate in late 2016. The study applied the rapid appraisal technique to investigate the factors influencing livestock sector, due to the difficulty to obtain data on financial and non-financial data from farms. Also the data was collected from specialists and experts in the field of animal production.

In addition, the study used secondary data of livestock sector for the period (2000-2015). The sources of secondary data were the Ministry of Agriculture and Land Reclamation (MALR), and Administration of Agriculture in Damietta, Department of livestock. In addition to the relevant studies done on this subject. SPSS was used to perform statistical analysis of the data collected from the survey forms.

\section{Results and Discussion}

\subsection{Actual Situation of Red Meat Production Sector}

This section provides a summary of the situation of red 
meat production sector in Egypt during (2000-2015). It is based on data from (MALR). Cow meat, buffalo meat, sheep meat, goats, and camel meat are considered the most important sources of red meat in Egypt. Table 1 presents mean and growth rate of the number of cows, buffalo, goats, sheep and camels in Egypt, 2000-2015. The total number of animal units is about 10084 thousand. This number is allocated to the cow, buffalo, goats, and sheep in the ratio $44.64 \%, 47.29 \%, 5.15 \%$, and $2.72 \%$, respectively. Thus buffalos and cows contribute together to about $91.93 \%$ of the total meat animal units in Egypt during the same period.

Table 1. Mean and Growth Rate of the Number of Meat Animals in Egypt, 2000-2015.

\begin{tabular}{llllllll}
\hline Item & Mean & \% & Constant & B & $\boldsymbol{R}^{\mathbf{2}}$ & F & Growth Rate \\
\hline Cows & 4501 & 44.64 & 3856.90 & 75.72 & 0.73 & $37.87^{* *}$ \\
Buffalo & 4769 & 47.29 & 4370.37 & 46.94 & 0.66 & $26.98^{* *}$ \\
Goats & 519 & 5.15 & 458.35 & 7.11 & 0.81 & $60.37^{* *}$ \\
Sheep & 274 & 2.72 & 238.80 & 4.17 & 0.85 & $81.88^{* *}$ \\
Camels & 106 & 1.05 & 101.77 & 0.49 & 0.05 & 0.78 \\
Total & 10084 & 100.00 & 8842.50 & 146.05 & 0.76 & 4.52 & 0.46 \\
\hline
\end{tabular}

Source: Calculated Based on Data from MALR, Various Issues.

${ }^{* *}$ Indicates significant at one percent level of significance.

The table shows that buffaloes come the first meat animals due to the relative importance of their animal units to the total number of meat animal units in Egypt during (20002015), represents about $47.29 \%$ of the total units number. Then cows come second as the number of their animal meat units represents about $44.64 \%$ in the same period of time. This means cows and buffalos are the main sources of red meat product in Egypt, because they are suitable for the Egyptian consumers tastes and preference. This attracts investors and institutions concerned with animal product of buffalos and cows.

During the period (2000-2015), it is observed that the number of cows increased from 3530 in 2000 to 5023 animal units in 2013. A simple linear trend shows that the number of cows increased by a significant annual growth rate of $1.68 \%$. The time trend variable is significant at the 0.01 probability level and it explains $73 \%$ of the variation in the number of cows. Buffalo slowly increased over the same period by a significant annual growth rate of $0.89 \%$. The number of goat and sheep grew at a significant annual rate of $1.376 \%$ and $1.52 \%$. While, camels showed a stagnant position during period (2000- 2015), resulting in stagnancy in red meat production from this source. During the same period, it is observed that the total number of meat animals increased from 8547.00 in 2000 to 11101 animal units in 2013. A simple linear trend analysis shows that the total number of meat animals units increased by 146.05 thousand animal unit/year, with an annual growth rate of $1.44 \%$. The time trend variable is significant at the 0.01 probability level and it explains $76 \%$ of the variation in the change of the meat animals numbers.

Table 2. The number of Cows, Buffalo, Goats and Sheep in Damietta, 2015(Figures in 000).

\begin{tabular}{|c|c|c|c|c|c|c|c|c|c|c|c|}
\hline \multirow{2}{*}{ District } & \multicolumn{2}{|l|}{ Cows } & \multicolumn{2}{|l|}{ Buffalo } & \multicolumn{2}{|l|}{ Sheep } & \multicolumn{2}{|c|}{ Goats } & \multicolumn{2}{|l|}{ Total } & \multirow{2}{*}{ - \% } \\
\hline & No. & Animal Unit & No. & Animal Unit & No. & Animal Unit & No. & Animal Unit & No. & Animal Unit & \\
\hline Damietta & 2125 & 2125 & 4198 & 5248 & 910 & 91 & 810 & 57 & 8832 & 7521 & 8.43 \\
\hline Fraskor & 8283 & 8283 & 23163 & 28954 & 3633 & 363 & 1489 & 104 & 37717 & 37704 & 42.25 \\
\hline Kafr Saad & 7458 & 7458 & 11555 & 14444 & 7323 & 732 & 2525 & 177 & 30011 & 22811 & 25.56 \\
\hline El zarka & 5077 & 5077 & 4045 & 5056 & 4511 & 451 & 844 & 59 & 17848 & 10643 & 11.93 \\
\hline Kafr Elbattikh & 2498 & 2498 & 6581 & 8226 & 3634 & 363 & 803 & 56 & 13854 & 11143 & 12.49 \\
\hline Governorat & 26453 & 26453 & 47934 & 59918 & 23995 & 2400 & 6605 & 462 & 104996 & 89233 & 100.00 \\
\hline
\end{tabular}

Animal Unit Cow=1, Buffalo=1.25, Sheep=0.10, Goat=0.07, Camel=0.75.

Source: Administration of Agriculture in Damietta, Department of livestock, Statistical records 2015 (Arabic).

Table 2, presents the number of meat animals and animal units of buffalo, cattle, goats and in Damietta Governorate of Egypt in 2015. The total number of meat animal units is about 89233 thousand units. This livestock numbers is allocated to the Farskor, Kafr Saad, Kafr El-battikh, El zarka and Damietta district in the ratio of $42.25 \%, 25.56 \%$, $12.49 \%$, and $8.43 \%$, respectively, the total meat animal units of Fraskor is the highest.

\subsection{Evaluating the Appropriateness of Factor Analysis}

Evaluating the appropriateness of factor analysis means assessing whether the variables are significantly and sufficiently correlated with each other so that their number can be reduced by applying the factor analysis. This can be done by a visual inspection of the correlation matrix. The correlation matrix provides an introspective view regarding the inter relationship among the variables (Carlos, M. et al. 2003). The First step in the analysis is an examination of the correlation matrix, presented in Table (2) in the appendix. The values in the table show that several variables are significantly correlated and strongly correlated. Therefore there is no way to demarcate the separate influence of the variables.

Further, there are certain diagnostic tests that affirm 
multicollinearity. The Kaiser Meyer Olkin measure of sampling adequacy is used to examine the appropriateness of factor analysis. The Kaiser Meyer Olkin value is 0.734 , which is greater than 0.5 , hence KMO test confirms the correlation among variables and factor analysis of the variable is feasible (Table 3). Moreover, this result has further been vindicated by the Bartlett's Test of Sphericity. It provides the statistical probability that correlation matrix has significant correlations among at least some of variables (Hair et al., 1998). This test has been applied to test the null hypothesis of spherical matrix. A chi-square test reject the null hypothesis of uncommon factor in favor of the alternative, that at least one common factor is presented, with a value of 1326.52 (with 210 degrees of freedom). It is suggested that if the Bartletts Test of Sphericity is significant, and if KMO exceeds 0.5 , then factorability is assumed. Based on the results in the table 3, the data matrix has sufficient correlations and the factor analysis is appropriate to be applied to the set of study data.
Table 3. Results of KMO and Bartlett's Test.

\begin{tabular}{ll}
\hline Kaiser - Meyer- Olkin (KMO) Measure of sampling adequacy & 0.734 \\
Bartlett's Test of Sphericity Approx. Chi-Squared & 1326.52 \\
Degree of freedom & 210 \\
Degree of Statistical Significance & 0.001 \\
\hline
\end{tabular}

Source: Statistical analysis results based on sample data, using SPSS 17.

A principal components method was applied in the analysis after the rotation to varimax. Table 4 displays the total variance explained in five stages for factors that influence red meat production. Five factors were extracted because their eigenvalues are greater than one which are capable to explain about $79.134 \%$ of the variance among variables, of which around $41.70 \%$ is explained by factor one and $15.2 \%$ is explained by factor two.

The principal component analysis method provides the relationship between the extracted factors and variable included in the analysis. The second run gives the results of un-rotated component matrix as illustrated in table 5.

Table 4. Factors Analysis for Meat Production: Explained Total Variance.

\begin{tabular}{|c|c|c|c|c|c|c|c|c|c|}
\hline \multirow{2}{*}{ Component } & \multicolumn{3}{|c|}{ Initial Eigenvalue } & \multicolumn{3}{|c|}{ Extraction Sum of Square Loading } & \multicolumn{3}{|c|}{ Rotation Sum of Square Loading } \\
\hline & Total & \%Variance & Cumulative & Total & \%Variance & Cumulative & Total & \%Variance & Cumulative \\
\hline 1 & 8.950 & 42.618 & 42.618 & 8.950 & 42.618 & 42.618 & 8.760 & 41.715 & 41.715 \\
\hline 2 & 3.192 & 15.198 & 57.816 & 3.192 & 15.198 & 57.816 & 3.199 & 15.235 & 56.950 \\
\hline 3 & 1.962 & 9.343 & 67.159 & 1.962 & 9.343 & 67.159 & 1.833 & 8.730 & 65.680 \\
\hline 4 & 1.331 & 6.337 & 73.495 & 1.331 & 6.337 & 73.495 & 1.463 & 6.965 & 72.645 \\
\hline 5 & 1.184 & 5.639 & 79.134 & 1.184 & 5.639 & 79.134 & 1.363 & 6.489 & 79.134 \\
\hline 6 & 1.022 & 4.882 & 84.016 & & & & & & \\
\hline 7 & 0.833 & 3.968 & 87.984 & & & & & & \\
\hline 8 & 0.771 & 3.671 & 91.655 & & & & & & \\
\hline 9 & 0.470 & 2.240 & 93.895 & & & & & & \\
\hline 10 & 0.423 & 2.014 & 95.909 & & & & & & \\
\hline 11 & 0.305 & 1.439 & 97.348 & & & & & & \\
\hline 12 & 0.251 & 1.197 & 98.544 & & & & & & \\
\hline 13 & 0.107 & 0.510 & 99.054 & & & & & & \\
\hline 14 & 0.069 & 0.328 & 99.382 & & & & & & \\
\hline 15 & 0.047 & 0.224 & 99.606 & & & & & & \\
\hline 16 & 0.043 & 0.204 & 99.810 & & & & & & \\
\hline 17 & 0.018 & 0.087 & 99.896 & & & & & & \\
\hline 18 & 0.014 & 0.066 & 99.962 & & & & & & \\
\hline 19 & 0.004 & 0.021 & 99.983 & & & & & & \\
\hline 20 & 0.003 & 0.012 & 99.995 & & & & & & \\
\hline 21 & 0.001 & 0.005 & 100.000 & & & & & & \\
\hline
\end{tabular}

Extraction Method: principal component analysis

Source: Statistical analysis results based on sample data, using SPSS 17.

Table 5. Un rotated Component Matrix (Principle Component Analysis).

\begin{tabular}{llccc}
\hline \multirow{2}{*}{ No } & Variable & Factors & & \\
\cline { 3 - 4 } & Number of animals each season & $\mathbf{1}$ & $\mathbf{2}$ & $\mathbf{3}$ \\
\hline 1 & Amount of production (in tons) & 0.986 & & \\
2 & Feed cost & 0.960 & & \\
3 & Cost of veterinary care & 0.954 & \\
4 & 0.950 & \\
5 & Value of the herd & 0.937 & \\
6 & Potential capacity & 0.920 & \\
7 & Current capacity & 0.919 & \\
8 & Labor cost & 0.915 & & \\
9 & Other costs & 0.902 & & \\
10 & Fixed costs & 0.620 & -0.367 & \\
11 & Farm size & 0.448 & & \\
12 & Profitability & & 0.943 & \\
13 & Net return per ton of meat & & \\
\hline
\end{tabular}




\begin{tabular}{llcccc}
\hline \multirow{2}{*}{ No } & Variable & Factors & & & \\
\cline { 3 - 6 } & & $\mathbf{1}$ & $\mathbf{2}$ & $\mathbf{3}$ & $\mathbf{4}$ \\
\hline 14 & Cost per ton & & -0.875 & & \\
15 & Source of animal & & 0.728 & \\
16 & Number of years of the farm operation & & 0.426 & 0.614 & -0.359 \\
17 & Livestock rearing experience (years) & -0.370 & & 0.573 & \\
18 & Weight at the beginning of fattening & & & 0.768 \\
19 & Number of sessions & & -0.385 & -0.428 & 0.699 \\
20 & Animal breed & & & 0.317 \\
21 & Animal species & & 0.465 & 0.552 \\
\hline
\end{tabular}

Source: Statistical analysis results based on sample data, using SPSS 17.

Factor analysis technique provides the facility of factor rotation to generate the orthogonal factors; accordingly, varimax technique of orthogonal with Kaiser Normalization has been used. The results are presented in the table 6. It clearly shows the orthogonal and the value of factor loadings clearly identifies each variable with factor. The variables with loadings greater than 0.40 were considered for interpretation purpose, as highly loaded. Factor loadings less than 0.40 are deleted from the table. Each factor is described based on these variables and assigned descriptive names. As shown in the table, the 21 variables are extracted into five factors.

Factor 1 consists of 11 items with factor loading ranging from 0.981 to 0.474 , the items factor1 are number of livestock, value of the herd, amount of production (in tons), feed cost, labor cost, cost of veterinary, Actual production capacity, production capacity, other costs, fixed costs and farm size. The number of meat animal heads is more positive saturated variables on the first factor. The component 1 was the combination of all these 11 items and this component could be interpreted as (Production Factor). component 1 contributed to $41.717 \%$ variation (table 6) of red meat production of the Damietta Governorate.

The economic analysis of sample data showed that the cost of herd represents from $42 \%$ to $63 \%$ of the total costs. The feed cost represents from $25 \%$ to $48 \%$ of the total cost. While veterinary care cost represents from 0.30 to $1.70 \%$ of total cost. While labor represents from $2.5 \%$ to $8 \%$ followed by veterinary care cost $(0.3 \%$ to $1.70 \%)$, other costs $(0.2$ to $1.30 \%$ ). Fixed costs ranged from 1.00 to $7.00 \% \%$ of the operating costs. The two main costs (herd and feed) represent respectively the $33 \%$ and the $21 \%$ of the total return.

Factor 2 consists of 3 items: profitability/LE., net return per ton and cost per ton of red meat and were significantly loaded with co-efficient values of $0.953,0.940$ and -0.885 respectively. These formed the second component (Financial Factor) by explaining $14.48 \%$ of variation in the red meat production. For the second factor, the net return per unit of red meat showed strong positive loading, and cost per ton of meat showed strong negative loadings. There is an inverse relation between the factor and the cost of meat per ton indicating the lower cost of production which leads to higher net return. This encourages the producers to increase production quantity of red meat. The financial analysis of the sample data showed that the net return per animal unit was 7.53 thousand LE, 30\% which is the highest among the producers of sample. The profitability was about 0.21 per pound.

The eigenvalue for the first component (Production) was notably greater than that of the second component (Financial) which showed the possibility of productivity improvement to a large extent.

Table 6. Rotated Component Matrix (Varimax Method with Kaiser Normalization).

\begin{tabular}{|c|c|c|c|c|c|c|}
\hline \multirow{2}{*}{ No } & \multirow{2}{*}{ Variable } & \multicolumn{5}{|c|}{ Factors } \\
\hline & & 1 & 2 & 3 & 4 & 5 \\
\hline 1 & Number of animals each season & 0.981 & & & & \\
\hline 2 & Value of the herd & 0.966 & & & & \\
\hline 3 & Amount of production (in tons) & 0.955 & & & & \\
\hline 4 & Feed cost & 0.955 & & & & \\
\hline 5 & Labor cost & 0.924 & & & & \\
\hline 6 & Cost of veterinary & 0.923 & & & & \\
\hline 7 & Actual production capacity & 0.901 & & & & \\
\hline 8 & Production capacity & 0.901 & & & & \\
\hline 9 & Other costs & 0.873 & & & & \\
\hline 10 & Fixed costs & 0.637 & & & & \\
\hline 11 & Farm size & 0.474 & & & & \\
\hline 12 & Profitability/LE. & & 0.963 & & & \\
\hline 13 & Net return per ton & & 0.938 & & & \\
\hline 14 & Cost per ton & & -0.890 & & & \\
\hline 15 & Number of years of the farm operation & & & 0.730 & & \\
\hline 16 & Source of animal & & & 0.672 & & \\
\hline 17 & Past experience & & & 0.648 & & \\
\hline 18 & Number of sessions & & & & 0.824 & \\
\hline 19 & Weight at the beginning of fattening & & & & 0.756 & \\
\hline 20 & Animal breed & & & & & 0.691 \\
\hline 21 & Type of product & & & & & 0.579 \\
\hline
\end{tabular}




\begin{tabular}{llllll}
\hline \multirow{2}{*}{ No Variable } & Factors & & & \\
\cline { 2 - 6 } & $\mathbf{1}$ & $\mathbf{2}$ & $\mathbf{3}$ & $\mathbf{4}$ & $\mathbf{5}$ \\
\hline Eigen value & 8.950 & 3.192 & 1.962 & 1.331 & 1.184 \\
Percentage of total variance & 41.715 & 15.235 & 8.730 & 6.965 & 6.489 \\
\hline
\end{tabular}

Source: Statistical analysis results based on sample data, using SPSS 17.

Table 7. Component Score Matrix.

\begin{tabular}{|c|c|c|c|c|c|c|}
\hline \multirow{2}{*}{ No } & \multirow{2}{*}{ Variable } & \multicolumn{5}{|c|}{ Factors } \\
\hline & & 1 & 2 & 3 & 4 & 5 \\
\hline 1 & Farm size & 0.063 & -0.074 & 0.150 & 0.058 & -0.047 \\
\hline 2 & Production capacity & 0.102 & 0.020 & -0.039 & 0.144 & -0.111 \\
\hline 3 & Actual production capacity & 0.103 & 0.022 & -0.052 & 0.146 & -0.088 \\
\hline 4 & Past experience & -0.035 & -0.041 & 0.368 & -0.058 & -0.138 \\
\hline 5 & Number of years of the farm operation & -0.021 & 0.118 & 0.421 & 0.036 & -0.164 \\
\hline 6 & Type of product & 0.021 & -0.026 & -0.175 & 0.031 & 0.471 \\
\hline 7 & Animal breed & 0.030 & 0.070 & 0.042 & -0.038 & 0.518 \\
\hline 8 & Source of animal & 0.078 & -0.021 & 0.349 & 0.112 & 0.222 \\
\hline 9 & Number of livestock & 0.116 & 0.012 & -0.024 & 0.014 & 0.050 \\
\hline 10 & Number of sessions & 0.021 & 0.035 & -0.025 & 0.566 & -0.175 \\
\hline 11 & Fixed costs & 0.070 & -0.107 & 0.197 & -0.058 & -0.122 \\
\hline 12 & Weight at the beginning of fattening & 0.040 & -0.102 & 0.084 & 0.556 & 0.230 \\
\hline 13 & Value of the breed & 0.128 & -0.056 & 0.028 & 0.083 & 0.086 \\
\hline 14 & Feed cost & 0.113 & -0.001 & 0.005 & -0.065 & 0.097 \\
\hline 15 & Cost of veterinary & 0.094 & -0.001 & -0.067 & -0.043 & -0.078 \\
\hline 16 & Labor cost & 0.109 & -0.037 & 0.031 & -0.082 & 0.081 \\
\hline 17 & Other costs & 0.090 & 0.037 & -0.078 & -0.031 & -0.031 \\
\hline 18 & Amount of production (in tons) & 0.114 & 0.043 & 0.001 & -0.027 & 0.118 \\
\hline 19 & Cost per ton & 0.003 & -0.285 & 0.096 & 0.029 & -0.178 \\
\hline 20 & Net return per ton & -0.022 & 0.296 & 0.061 & -0.024 & -0.089 \\
\hline 21 & Profitability/LE. & -0.011 & 0.305 & 0.036 & -0.045 & -0.014 \\
\hline
\end{tabular}

Source: Statistical analysis results based on sample data, using SPSS 17.

Factor 3. mainly illustrates the administrative items, hence, it called (Administrative Factor). Factor 3 comprised of 3 variables with factor loadings ranging from 0.730 to 0.648 . The items in factor 3 are the number of years of the farm operation, source of animal and previous experience. The third factor accounted for $8.730 \%$ of the variations. This factor showed the importance of the number of years of farm operation, the source of animal and previous experience. The two items that load on factor 4 number of production sessions and the weight of animal at the beginning of fatting process. The number of production sessions associated with the weight of animal at the beginning of fatting. The high weight of animal leads to more production courses in a special time. This factor is a reasonable representation of the biological items. Therefore, it is called (Biological Factor).

Finally, variables loaded for factor 5 are related to animal breed and type of animal, which were significantly loaded with co-efficient values of 0.691 and 0.579 respectively. This was labeled (Technological Factor) component 5 contributed to $6.489 \%$ variation of red meat production of Damietta Governorate.

This can be useful when planning to increase the production of red meat by selecting type and strain of animals with higher productivity. And at the same time, more effort should be exerted to raise the productivity of animal types using improved genetic techniques; introducing high yield genetics as means to increase red meat production.

Five new factors were successfully constructed using factor analysis and assigned as the factors influencing the red meat production. Table 8 shows the names of new factors and percentage of variance explains when it was extracted. When the first factor was extracted, then $41.715 \%$ of variance would be explained.

The results showed the importance of the technological factor. The source of the animal is correlated with production, administrative and technological factors. Also The correlation between technological factor and the weight at the beginning of fattening, and its correlation with biological factor. This indicates the saturation of animal breeding and type correlated with the source of the animal and the weight at the beginning of fatting. This indicates that farmers breed used foreign breeding animals with more productivity and to select the source of animal which has a high efficiency in meat production. Increasing the productivity of each animal is the most efficient way of producing more meat, through selecting the source of animal and breeding which achieve higher productivity.

Table 8. Name of New Factors with Percentage of Variance.

\begin{tabular}{lll}
\hline Factor & Name & \% Variance \\
\hline 1 & Production Factor & 41.715 \\
2 & Financial Factor & 15.235 \\
3 & Administrative Factor & 8.730 \\
4 & Bio-Factor & 6.965 \\
5 & Technological Factor & 6.489 \\
\hline
\end{tabular}

Source: Statistical analysis results based on sample data, using SPSS 17. 


\subsection{Challenges Facing Red Meat Producers in Damietta Governorate}

There are many problems and challenges facing the producers of red meat in the study area such as productivity problems and marketing problems, which appeared during the field study. Productivity problems were high feed prices, high labor cost, lack of professional labor, the spread of foot and mouth disease, the high cost of veterinary medicines, high interest of loans for meat producers and feed shortage. Marketing problems, inequality prices, instability of sales, lack of market information, monopoly practices of some traders, seasonal changes of demand. This leads to deterioration in the red meat sector.

By using the variance analysis to identify the causes of productivity problems, there were statistically significant differences between causes of productivity problems at probability level of 0.01 . Using the method of the least significant difference to arrange the causes of productivity problems, according to their relative importance, as shown in table 9 and 10, it appears that the high prices, high cost of labor, risk cost and high cost of animal breeding were among the first producers concerns, because there were no significant statistical differences among the causes. While poor quality of breed, the weakness of preventive and extension efforts, high cost of loan, shortages of feed, lack of skilled labor, were in the second order.
Lack of suitable diseases vaccine and nutrition problem are the most important because they require supplying of feed at reasonable prices.

Red meat producers generally use the available local feed resources, such as crop residues, grass, forage crops, and local feedstuffs (agro-industrial product). This requires an expansion in the cultivated area of fodder crops, the stability of prices for animals fatting, providing effective treatment and appropriate vaccines.

Using variance analysis to identify the causes of marketing problems, there was statistically significant differences between causes of marketing problems at probability level of 0.01 . Using the method of the least significant difference to arrange the causes of marketing problems, according to their relative importance, as shown in table 11. Using the least significance difference, as shown in table 12, it appears that dumping and fear of diseases together came in the first order. While the fear of disease and lack of marketing organization and slaughtering young calves were in the second order, since there were no significant statistical differences. Finally, lack of marketing information, and seasonal changes in demand came in the fifth rank.

Achieving reasonable prices of production needs to increase the tariff imposed on red meat, ration of red meat, stability of sales, ban on slaughter young claves, increasing the sales and marketing outlets for red meat sector.

Table 9. Variance Analysis for Productivity Problem Causes.

\begin{tabular}{|c|c|c|c|c|}
\hline Sources of variation & Freedom Degrees & Sum of Squares (SS) & Mean Sum of Squares (MS) & $F$-statistic \\
\hline Between the reasons & 9 & 944.980 & 104.988 & $27.748 * *$ \\
\hline Within the reasons & 440 & 1664.978 & 3.784 & \\
\hline Total & 449 & 2609.958 & & \\
\hline
\end{tabular}

Source: Statistical analysis results based on Questionnaire sample survey in 2016.

Table 10. The Ranks of Productivity Problem Causes, L. S. D at 0.01 and 0.05

\begin{tabular}{|c|c|c|c|c|c|c|}
\hline \multirow{2}{*}{ No } & \multirow{2}{*}{ Causes } & \multirow{2}{*}{ Average } & \multirow{2}{*}{ Rank } & \multicolumn{3}{|c|}{ Group } \\
\hline & & & & 1 & 2 & 3 \\
\hline $\mathrm{X}_{1}$ & High cost of labor & 2.13 & $\mathrm{X}_{3}$ & 1.55 & & \\
\hline $\mathrm{X}_{2}$ & Lack of professional labor & 4.69 & $\mathrm{X}_{1}$ & 2.13 & & \\
\hline $\mathrm{X}_{3}$ & High feed prices & 1.55 & $\mathrm{X}_{10}$ & 2.20 & & \\
\hline $\mathrm{X}_{4}$ & Feed shortage & 4.58 & $\mathrm{X}_{5}$ & 2.40 & & \\
\hline $\mathrm{X}_{5}$ & High value of animal breed & 2.40 & $\mathrm{X}_{6}$ & & 4.06 & \\
\hline $\mathrm{X}_{6}$ & Poor quality of animal breed & 4.06 & $\mathrm{X}_{7}$ & & 4.07 & \\
\hline $\mathrm{X}_{8}$ & High cost of veterinary medicines & 6.45 & $\mathrm{X}_{4}$ & & 4.58 & \\
\hline $\mathrm{X}_{9}$ & High Cost of loans & 4.20 & $\mathrm{X}_{2}$ & & 4.69 & \\
\hline $\mathrm{X}_{10}$ & Risk & 2.20 & $\mathrm{X}_{8}$ & & & 6.45 \\
\hline
\end{tabular}

L. S. D. value at $0.05=0.20$, L. S. D. value at $0.01=0.26$

Source: Statistical analysis results based on Questionnaire sample survey in 2016.

Table 11. Variance Analysis Marketing Problem Causes.

\begin{tabular}{llll}
\hline Sources of variation & Freedom Degrees & Sum of Squares (SS) & Mean Sum of Squares (MS) \\
\hline Between the reasons & 9 & 1391.636 & 154.626 \\
Within the reasons & 440 & 1020.622 & 2.320 \\
Total & 449 & 2412.258 & \\
\hline
\end{tabular}

Source: Statistical analysis results based on Questionnaire sample survey in 2016. 
Table 12. The Ranks of Marketing Problem Causes, L. S. D at 0.01 and 0.05 .

\begin{tabular}{|c|c|c|c|c|c|c|c|c|}
\hline \multirow{2}{*}{ No } & \multirow{2}{*}{ Causes } & \multirow{2}{*}{ Average } & \multirow{2}{*}{ Rank } & \multicolumn{5}{|c|}{ Group } \\
\hline & & & & 1 & 2 & 3 & 4 & 5 \\
\hline $\mathrm{X}_{1}$ & Inequality prices & 4.80 & $\mathrm{X}_{2}$ & 1.80 & & & & \\
\hline $\mathrm{X}_{2}$ & Dumping & 1.80 & $\mathrm{X}_{7}$ & 2.11 & 2.11 & & & \\
\hline $\mathrm{X}_{3}$ & Instability of sales & 5.22 & $\mathrm{X}_{6}$ & & 2.69 & 2.69 & & \\
\hline $\mathrm{X}_{4}$ & Slaughter young calves & 2.71 & $\mathrm{X}_{4}$ & & 2.71 & 2.71 & & \\
\hline $\mathrm{X}_{5}$ & Lack of market information & 6.44 & $\mathrm{X}_{8}$ & & & 3.04 & & \\
\hline $\mathrm{X}_{6}$ & Lack of marketing organization & 2.69 & $\mathrm{X}_{9}$ & & & & 4.69 & \\
\hline $\mathrm{X}_{7}$ & Fear of diseases & 2.11 & $\mathrm{X}_{1}$ & & & & 4.80 & \\
\hline $\mathrm{X}_{8}$ & Monopoly of some traders & 3.04 & $\mathrm{X}_{3}$ & & & & 5.22 & \\
\hline $\mathrm{X}_{9}$ & Lack of adequate market & 6.44 & $\mathrm{X}_{5}$ & & & & & 6.44 \\
\hline $\mathrm{X}_{10}$ & Seasonal changes of demand & 7.11 & $\mathrm{X}_{10}$ & & & & & 7.11 \\
\hline
\end{tabular}

L. S. D. value at $0.05=0.20$, L. S. D. value at $0.01=0.26$

Source: Statistical analysis results based on Questionnaire sample survey in 2016.

\section{Conclusions and Recommendations}

The results showed five new factors which were successfully constructed by using factor analysis and assigned as the factors influencing the meat production; which are production factor, financial factor, administrative factor, biological factor and technological factor. Factor analysis results indicated that effective factors production and financial factor are important in producing red meat. The most important factors influencing red meat production are the number of animal units, and the volume of concentrated feed. Feed cost is a significant component of the cost of producing red meat. As everyone knows, this indicates that number of meat animal heads plays an important role in increasing meat production. There is a potential of productivity improvement to a large extent. On large farm scale basis, the lower cost of production leads to higher net return, which encourages producers to increase production. Also, The success of livestock enterprise depends on a prior experience in the field of animal production, selecting animal and breeding type.

The nutrition problem is one of the most important production problems facing the red meat sector, while the high feed price is the most important cause that limits red meat production. As well as the marketing problem, the increase of imported red meat and fear of diseases were the key challenges for determining producer prices. The consequence of these reasons result in instability of sector production and deterioration in red meat sector.

Based on the results, the study recommends the following:

- There is a need to increase investments in the red meat sector in Egypt, besides facilitating the procedures of animal loans.

- Encouraging the producers to increase the number of red meat animals with high meat productivity. This can be achieved by funding the producers and facilitating the production system of livestock.

- Increasing fodder supply through extend the existing area of fodder crops and cultivation of high yielding varieties,

- Providing effective treatment and appropriate vaccines that are important items for increasing animal production.

- Application of advanced biotechnology and feed processing technology.

- Asserting not to slaughter young calves before they are fattened to the optimum weight at slaughter time.

- Policy maker should consider low cost loan to promote the production in a positive way.

- Increasing the investments in technology improvements in livestock production, encouraging the adoption of new bio-technologies in livestock production.

\section{Appendix}

Table A1. Trends in the Number of of Cows, Buffalo, Goats, Sheep and Camels in Egypt, 2000-2015 (Figures in 000).

\begin{tabular}{|c|c|c|c|c|c|c|c|c|c|c|c|c|}
\hline \multirow{2}{*}{ Years } & \multicolumn{2}{|l|}{ Cows } & \multicolumn{2}{|c|}{ Buffalo } & \multicolumn{2}{|c|}{ Sheep } & \multicolumn{2}{|l|}{ Goats } & \multicolumn{2}{|c|}{ Camels } & \multicolumn{2}{|l|}{ Total } \\
\hline & \begin{tabular}{|l|} 
No. \\
\end{tabular} & Animal Unit & No. & Animal Unit & $\begin{array}{l}\text { No. } \\
\end{array}$ & Animal Unit & \begin{tabular}{|l|} 
No. \\
\end{tabular} & Animal Unit & $\begin{array}{l}\text { No. } \\
\end{array}$ & Animal Unit & \begin{tabular}{|l|} 
No. \\
\end{tabular} & Animal Unit \\
\hline 2000 & 3530 & 3530 & 3530 & 4224 & 4469 & 447 & 3425 & 240 & 142 & 107 & 14944 & 8547 \\
\hline 2001 & 3801 & 3801 & 3378 & 4224 & 4469 & 447 & 3425 & 240 & 142 & 107 & 14944 & 8547 \\
\hline 2002 & 4012 & 4012 & 3533 & 4416 & 4671 & 467 & 3491 & 244 & 134 & 101 & 15630 & 9029 \\
\hline 2003 & 4369 & 4369 & 3777 & 4721 & 4939 & 494 & 3811 & 267 & 136 & 102 & 16890 & 9811 \\
\hline 2004 & 4227 & 4227 & 3717 & 4646 & 5105 & 511 & 3582 & 251 & 127 & 95 & 16543 & 9515 \\
\hline 2005 & 4485 & 4485 & 3845 & 4806 & 5043 & 504 & 3879 & 272 & 129 & 97 & 17265 & 10048 \\
\hline 2006 & 4515 & 4515 & 3885 & 4856 & 5232 & 523 & 3803 & 266 & 142 & 107 & 17547 & 10237 \\
\hline 2007 & 4680 & 4680 & 3897 & 4871 & 5289 & 529 & 3880 & 272 & 145 & 109 & 17726 & 10296 \\
\hline 2008 & 5023 & 5023 & 3915 & 4894 & 5311 & 531 & 3920 & 274 & 159 & 119 & 17985 & 10499 \\
\hline 2009 & 4524 & 4524 & 4052 & 5065 & 5498 & 550 & 4237 & 297 & 165 & 124 & 18975 & 11058 \\
\hline
\end{tabular}




\begin{tabular}{|c|c|c|c|c|c|c|c|c|c|c|c|c|}
\hline \multirow{2}{*}{ Years } & \multicolumn{2}{|l|}{ Cows } & \multicolumn{2}{|c|}{ Buffalo } & \multicolumn{2}{|c|}{ Sheep } & \multicolumn{2}{|c|}{ Goats } & \multicolumn{2}{|c|}{ Camels } & \multicolumn{2}{|l|}{ Total } \\
\hline & No. & Animal Unit & No. & Animal Unit & No. & Animal Unit & No. & Animal Unit & No. & Animal Unit & No. & Animal Unit \\
\hline 2010 & 4728 & 4728 & 3838 & 4798 & 5591 & 559 & 4139 & 290 & 137 & 103 & 18229 & 10273 \\
\hline 2012 & 4946 & 4946 & 3983 & 4979 & 5365 & 537 & 4258 & 298 & 136 & 102 & 18521 & 10694 \\
\hline 2013 & 4745 & 4745 & 4164 & 5205 & 5429 & 543 & 4306 & 301 & 141 & 106 & 18986 & 11101 \\
\hline 2014 & 4762 & 4762 & 3915 & 4894 & 5564 & 556 & 4153 & 291 & 152 & 114 & 18529 & 10600 \\
\hline 2015 & 4883 & 4883 & 3950 & 4938 & 5502 & 550 & 4180 & 293 & 158 & 119 & 18552 & 10661 \\
\hline \multicolumn{2}{|c|}{ Average } & 4501 & & 4769 & & 519 & & 274 & & 106 & & 10084 \\
\hline \multicolumn{2}{|c|}{$\%$} & 45 & & 47 & & 5 & & 3 & & 1 & & 100 \\
\hline
\end{tabular}

Animal Unit Cow=1, Buffalo=1.25, Sheep=0.10, Goats=0.07, Camels=0.75.

Source: Central Agency for Public Mobilization and Statistics (CAPMAS), Statistics of Animal Wealth, different issues (in Arabic).

Table A2. Presents the Correlation Matrix Ratios.

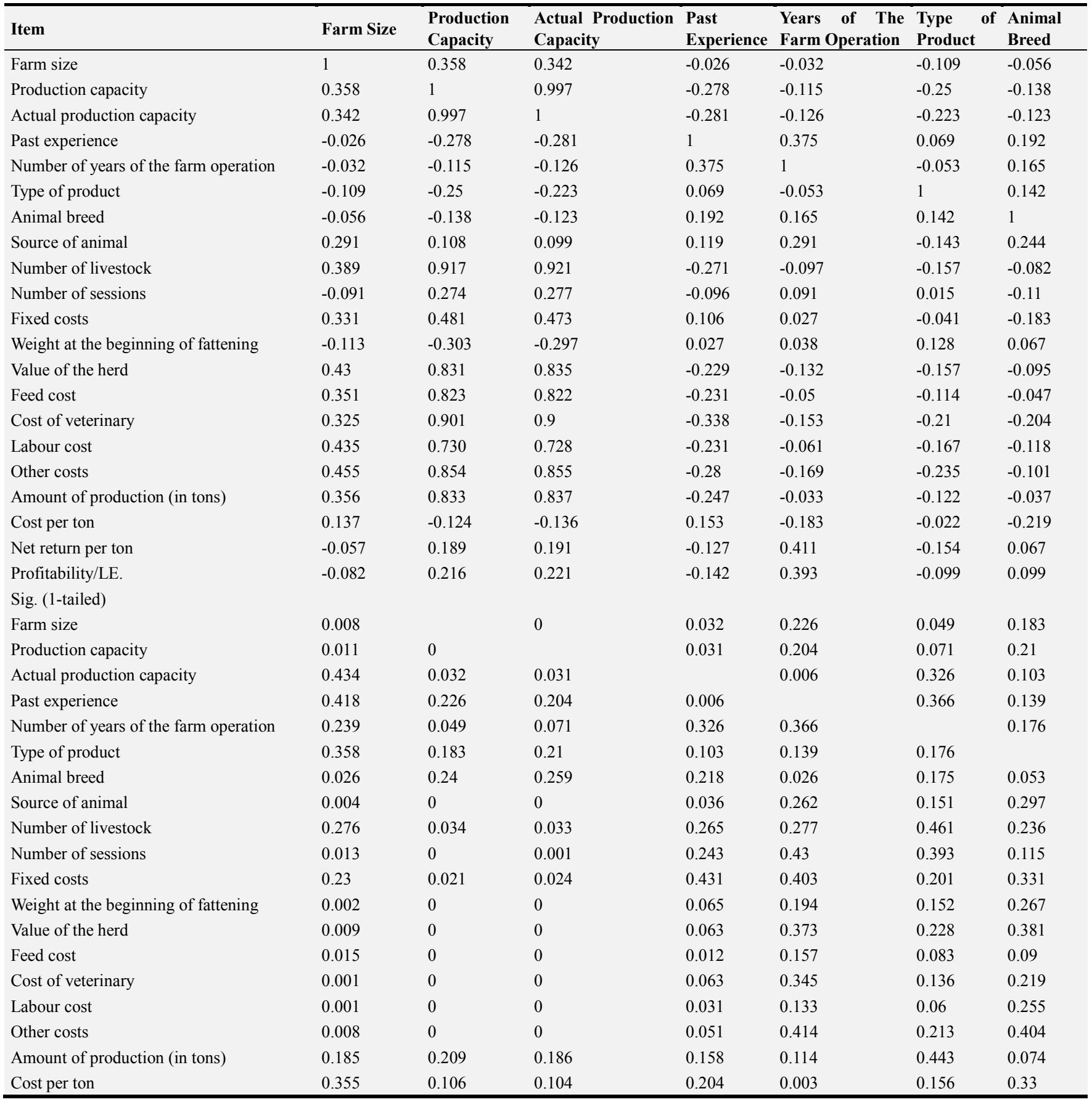




\begin{tabular}{|c|c|c|c|c|c|c|c|}
\hline Item & Farm Size & $\begin{array}{l}\text { Production } \\
\text { Capacity } \\
\end{array}$ & $\begin{array}{l}\text { Actual Production } \\
\text { Capacity }\end{array}$ & $\begin{array}{l}\text { Past } \\
\text { Experience }\end{array}$ & $\begin{array}{l}\text { Years of The } \\
\text { Farm Operation }\end{array}$ & $\begin{array}{l}\text { Type of } \\
\text { Product }\end{array}$ & $\begin{array}{l}\text { Animal } \\
\text { Breed }\end{array}$ \\
\hline Net return per ton & 0.297 & 0.077 & 0.073 & 0.176 & 0.004 & 0.259 & 0.258 \\
\hline Profitability/LE. & 1.000 & 0.358 & 0.342 & -0.026 & -0.032 & -0.109 & -0.056 \\
\hline
\end{tabular}

Table A2. Continue.

\begin{tabular}{|c|c|c|c|c|c|c|c|}
\hline Item & $\begin{array}{l}\text { Source of } \\
\text { Animal } \\
\end{array}$ & $\begin{array}{l}\text { Number of } \\
\text { Livestock }\end{array}$ & $\begin{array}{l}\text { Number of } \\
\text { Sessions }\end{array}$ & $\begin{array}{l}\text { Fixed } \\
\text { Costs } \\
\end{array}$ & $\begin{array}{l}\text { Weight at The } \\
\text { Beginning of Fattening }\end{array}$ & $\begin{array}{l}\text { Value of } \\
\text { The Herd } \\
\end{array}$ & $\begin{array}{l}\text { Feed } \\
\text { Cost }\end{array}$ \\
\hline Farm size & 0.291 & 0.389 & -0.091 & 0.331 & -0.113 & 0.43 & 0.351 \\
\hline Production capacity & 0.108 & 0.917 & 0.274 & 0.481 & -0.303 & 0.831 & 0.823 \\
\hline Actual production capacity & 0.099 & 0.921 & 0.277 & 0.473 & -0.297 & 0.835 & 0.822 \\
\hline Past experience & 0.119 & -0.271 & -0.096 & 0.106 & 0.027 & -0.229 & -0.231 \\
\hline Number of years of the farm operation & 0.291 & -0.097 & 0.091 & 0.027 & 0.038 & -0.132 & -0.05 \\
\hline Animal breed & 0.244 & -0.082 & -0.11 & -0.183 & 0.067 & -0.095 & -0.047 \\
\hline Source of animal & 1 & 0.266 & -0.19 & 0.327 & 0.166 & 0.357 & 0.33 \\
\hline Number of livestock & 0.266 & 1 & -0.016 & 0.562 & -0.332 & 0.949 & 0.959 \\
\hline Number of sessions & -0.19 & -0.016 & 1 & -0.185 & 0.313 & -0.086 & -0.159 \\
\hline Fixed costs & 0.327 & 0.562 & -0.185 & 1 & -0.253 & 0.621 & 0.612 \\
\hline Weight at the beginning of fattening & 0.166 & -0.332 & 0.313 & -0.253 & 1 & -0.146 & -0.356 \\
\hline Feed cost & 0.33 & 0.959 & -0.159 & 0.612 & -0.356 & 0.920 & 1 \\
\hline Cost of veterinary & 0.132 & 0.930 & -0.014 & 0.589 & -0.432 & 0.862 & 0.887 \\
\hline Labour cost & 0.354 & 0.909 & -0.28 & 0.597 & -0.282 & 0.921 & 0.938 \\
\hline Other costs & 0.1 & 0.875 & 0.021 & 0.46 & -0.39 & 0.787 & 0.812 \\
\hline Amount of production (in tons) & 0.341 & 0.963 & -0.094 & 0.575 & -0.298 & 0.918 & 0.961 \\
\hline Cost per ton & -0.028 & -0.128 & -0.235 & 0.29 & 0.096 & 0.062 & -0.055 \\
\hline Net return per ton & 0.061 & 0.125 & 0.231 & -0.185 & -0.134 & -0.019 & 0.05 \\
\hline Profitability/LE. & 0.09 & 0.185 & 0.208 & -0.141 & -0.155 & 0.023 & 0.135 \\
\hline \multicolumn{8}{|l|}{ Sig. (1-tailed) } \\
\hline Farm size & 0.24 & 0 & 0.034 & 0 & 0.021 & 0 & 0 \\
\hline Production capacity & 0.259 & 0 & 0.033 & 0.001 & 0.024 & 0 & 0 \\
\hline Actual production capacity & 0.218 & 0.036 & 0.265 & 0.243 & 0.431 & 0.065 & 0.063 \\
\hline Past experience & 0.026 & 0.262 & 0.277 & 0.43 & 0.403 & 0.194 & 0.373 \\
\hline Animal breed & & 0.038 & 0.106 & 0.014 & 0.139 & 0.008 & 0.014 \\
\hline Source of animal & 0.038 & & 0.459 & 0 & 0.013 & 0 & 0 \\
\hline Number of livestock & 0.106 & 0.459 & & 0.112 & 0.018 & 0.287 & 0.149 \\
\hline Number of sessions & 0.014 & 0 & 0.112 & & 0.046 & 0 & 0 \\
\hline Fixed costs & 0.139 & 0.013 & 0.018 & 0.046 & & 0.169 & 0.008 \\
\hline Weight at the beginning of fattening & 0.008 & 0 & 0.287 & 0 & 0.169 & & 0 \\
\hline Value of the herd & 0.014 & 0 & 0.149 & 0 & 0.008 & 0 & \\
\hline Feed cost & 0.193 & 0 & 0.463 & 0 & 0.002 & 0 & 0 \\
\hline Cost of veterinary & 0.009 & 0 & 0.031 & 0 & 0.03 & 0 & 0 \\
\hline labour cost & 0.257 & 0 & 0.445 & 0.001 & 0.004 & 0 & 0 \\
\hline Other costs & 0.011 & 0 & 0.271 & 0 & 0.024 & 0 & 0 \\
\hline Amount of production (in tons) & 0.426 & 0.202 & 0.06 & 0.026 & 0.266 & 0.342 & 0.36 \\
\hline Cost per ton & 0.345 & 0.206 & 0.063 & 0.112 & 0.19 & 0.45 & 0.372 \\
\hline Net return per ton & 0.277 & 0.112 & 0.085 & 0.178 & 0.154 & 0.44 & 0.189 \\
\hline Profitability/LE. & 0.291 & 0.389 & -0.091 & 0.331 & -0.113 & 0.43 & 0.351 \\
\hline
\end{tabular}

Table A2. Continue.

\begin{tabular}{|c|c|c|c|c|c|c|c|}
\hline Item & $\begin{array}{l}\text { Cost of } \\
\text { Veterinary }\end{array}$ & $\begin{array}{l}\text { Labor } \\
\text { Cost }\end{array}$ & $\begin{array}{l}\text { Other } \\
\text { Costs }\end{array}$ & $\begin{array}{l}\text { Amount of } \\
\text { Production (in tons) }\end{array}$ & $\begin{array}{l}\text { Cost Per } \\
\text { Ton }\end{array}$ & $\begin{array}{l}\text { Net Return } \\
\text { Per Ton } \\
\end{array}$ & Profitability. \\
\hline Farm size & 0.325 & 0.435 & 0.455 & 0.356 & 0.137 & -0.057 & -0.082 \\
\hline Production capacity & 0.901 & 0.730 & 0.854 & 0.833 & -0.124 & 0.189 & 0.216 \\
\hline
\end{tabular}




\begin{tabular}{|c|c|c|c|c|c|c|c|}
\hline Actual production capacity & 0.9 & 0.728 & 0.855 & 0.837 & -0.136 & 0.191 & 0.221 \\
\hline Past experience & -0.338 & -0.231 & -0.28 & -0.247 & 0.153 & -0.127 & -0.142 \\
\hline Number of years of the farm operation & -0.153 & -0.061 & -0.169 & -0.033 & -0.183 & 0.411 & 0.393 \\
\hline Type of product & -0.21 & -0.167 & -0.235 & -0.122 & -0.022 & -0.154 & -0.099 \\
\hline Animal breed & -0.204 & -0.118 & -0.101 & -0.037 & -0.219 & 0.067 & 0.099 \\
\hline Source of animal & 0.132 & 0.354 & 0.1 & 0.341 & -0.028 & 0.061 & 0.09 \\
\hline number of livestock & 0.93 & 0.909 & 0.875 & 0.963 & -0.128 & 0.125 & 0.185 \\
\hline Number of sessions & -0.014 & -0.28 & 0.021 & -0.094 & -0.235 & 0.231 & 0.208 \\
\hline Fixed costs & 0.589 & 0.597 & 0.46 & 0.575 & 0.29 & -0.185 & -0.141 \\
\hline Weight at the beginning of fattening & -0.432 & -0.282 & -0.39 & -0.298 & 0.096 & -0.134 & -0.155 \\
\hline Value of the herd & 0.862 & 0.921 & 0.787 & 0.918 & 0.062 & -0.019 & 0.023 \\
\hline Feed cost & 0.887 & 0.938 & 0.812 & 0.961 & -0.055 & 0.05 & 0.135 \\
\hline Cost of veterinary & 1 & 0.857 & 0.856 & 0.874 & -0.028 & 0.073 & 0.119 \\
\hline Labour cost & 0.857 & 1 & 0.759 & 0.916 & 0.026 & -0.043 & 0.027 \\
\hline Other costs & 0.856 & 0.759 & 1 & 0.851 & -0.235 & 0.132 & 0.202 \\
\hline Amount of production (in tons) & 0.874 & 0.916 & 0.851 & 1 & -0.24 & 0.194 & 0.292 \\
\hline Cost per ton & -0.028 & 0.026 & -0.235 & -0.24 & 1 & -0.745 & -0.828 \\
\hline Net return per ton & 0.073 & -0.043 & 0.132 & 0.194 & -0.745 & 1 & 0.974 \\
\hline Profitability/LE. & 0.119 & 0.027 & 0.202 & 0.292 & -0.828 & 0.974 & 1 \\
\hline \multicolumn{8}{|l|}{ Sig. (1-tailed) } \\
\hline Farm size & 0 & 0 & 0 & 0 & 0.209 & 0.106 & 0.077 \\
\hline Production capacity & 0 & 0 & 0 & 0 & 0.186 & 0.104 & 0.073 \\
\hline Actual production capacity & 0.012 & 0.063 & 0.031 & 0.051 & 0.158 & 0.204 & 0.176 \\
\hline Past experience & 0.157 & 0.345 & 0.133 & 0.414 & 0.114 & 0.003 & 0.004 \\
\hline Number of years of the farm operation & 0.083 & 0.136 & 0.06 & 0.213 & 0.443 & 0.156 & 0.259 \\
\hline Type of product & 0.09 & 0.219 & 0.255 & 0.404 & 0.074 & 0.33 & 0.258 \\
\hline Animal breed & 0.193 & 0.009 & 0.257 & 0.011 & 0.426 & 0.345 & 0.277 \\
\hline Source of animal & 0 & 0 & 0 & 0 & 0.202 & 0.206 & 0.112 \\
\hline number of livestock & 0.463 & 0.031 & 0.445 & 0.271 & 0.06 & 0.063 & 0.085 \\
\hline Number of sessions & 0 & 0 & 0.001 & 0 & 0.026 & 0.112 & 0.178 \\
\hline Fixed costs & 0.002 & 0.03 & 0.004 & 0.024 & 0.266 & 0.19 & 0.154 \\
\hline Weight at the beginning of fattening & 0 & 0 & 0 & 0 & 0.342 & 0.45 & 0.44 \\
\hline Value of the herd & 0 & 0 & 0 & 0 & 0.36 & 0.372 & 0.189 \\
\hline Feed cost & & 0 & 0 & 0 & 0.427 & 0.317 & 0.219 \\
\hline Cost of veterinary & 0 & & 0 & 0 & 0.432 & 0.389 & 0.43 \\
\hline Labor cost & 0 & 0 & & 0 & 0.06 & 0.195 & 0.091 \\
\hline Other costs & 0 & 0 & 0 & & 0.056 & 0.101 & 0.026 \\
\hline Amount of production (in tons) & 0.427 & 0.432 & 0.06 & 0.056 & & 0 & 0 \\
\hline Cost per ton & 0.317 & 0.389 & 0.195 & 0.101 & 0 & & 0 \\
\hline Net return per ton & 0.219 & 0.43 & 0.091 & 0.026 & 0 & 0 & \\
\hline Profitability/LE. & 0.325 & 0.435 & 0.455 & 0.356 & 0.137 & -0.057 & -0.082 \\
\hline
\end{tabular}

Source: by researcher depending on sample data, using SPSS 17.

Determinant $=6.98 \mathrm{E}-02$

\section{References}

[1] Amin F and Lyne M. C. (1994) Econometric Analysis of Private Accesses to Communal Grazing Land in South Africa. A case study of Ciskei. Agricultural System Vol.46, Issue 4, p 461-471.

[2] Anderson, T. W. (2003) An Introduction to Multivariate Statistical Analysis. Wiley, New York, Third edition, 89-90.

[3] BRYNAF, J. M. (1994) Multivariate Statistical Method, Champman \& Hall, USA, New York, 1994, 34.

[4] CAPMAS. Central Agency for Public Mobilization and
Statistics, Statistics of Animal Wealth, different issues, Egypt.

[5] Carlos. M. and Ferreir A. M. A. (2003) Multivariate Methodology to Uncover Regional Disparities : A contribution to Improve European Union and Governmental Decisions, European Journal of Operational Research, 145, 121-135.

[6] Dawoud, S. (2005) Analysis of Food Consumption Patterns in Egypt", Ph. D. Dissertation p. 209, Department of Food Economics, and Consumption Studies, Faculty of Agriculture and Food Science, Christian-Albrechts-University at Kiel, Germany.

[7] Garson, G. D. (2008) Factor Analysis, from Statnotes: Topics in multivariate analysis. http://faculty.chass.ncsu.edu/garson/pa765/factor.htm. 
[8] Hair, J. F., Anderson, R. E., Tham, R. L. and Black, W. C. (1998) Multivariate data analysis (5 th edition) New Jersey: Prentce Hall.

[9] Helal, A. F. R. (2015) An Economic Study for Production and Marketing the red Meat in Arab Republic of Egypt, department of Agricultural Economics, Al-Azhar University, Cairo, Egypt.

[10] MALR. Ministry of Agriculture and Land Reclamation,
Economic Affairs Sector, Agricultural Statistics Bulletin, Different Issues, Egypt.

[11] Stewart, D. W. (1981) The Application and Misapplication of Factor Analysis in Marketing Research. Journal of Marketing Research, 18(1), 51-62.

[12] Tabachnick. B. and Fidell. L. (1989) Using Multivariate Statistics, Harper\&Row Publisher, USA, New York, 746. 